\title{
PENGGUNAAN SECONDARY SURVEILLANCE RADAR UNTUK PENENTUAN POSISI PESAWAT UDARA
}

\author{
Akhmad Hafidz Irfandi, Muhammad Taufik \\ Jurusan Teknik Geomatika, Fakultas Teknik Sipil dan Perencanaan \\ Institut Teknologi Sepuluh Nopember (ITS) \\ Jl. Arief Rahman Hakim, Surabaya 60111 Indonesia \\ e-mail: taufik_srmd@yahoo.com
}

\begin{abstract}
Abstrak
Republik Indonesia merupakan negara kepulauan terbesar di dunia yang memiliki lebih dari 17.000 pulau dengan pertumbuhan demografi yang sangat pesat, hal ini menjadikan Indonesia sebagai negara berpenduduk terbesar keempat di dunia. Pesawat udara merupakan alat transportasi yang paling efektif dalam mendukung mobilitas penduduk.

Navigasi atau pandu arah adalah penentuan kedudukan (position) dan arah perjalanan baik di medan sebenarnya atau di peta. Navigasi ini dilakukan pada pesawat udara yang dipandu dari darat melalui sinyal yang dipancarkan oleh instrumen terpasang pada menara (ground base) maupun sinyal dari satelit (satellite base).

Dalam navigasi ada beberapa macam radar yang umum digunakan yaitu Primary Surveillance Radar (PSR) dan Secondary Surveillance Radar (SSR). Kedua jenis radar baik PSR maupun SSR mempunyai cara kerja berbeda. Pada PSR sifatnya aktif dan pesawat yang ditargetkan sifatnya pasif.Karena PSR hanya menerima pantulan gelombang radio dari refleksi pesawat tersebut (echo).Sedangkan pesawat itu sendiri tidak ikut aktif dengan pancaran sinyal radar di bawah. Pada SSR, baik radar maupun pesawat kedua-duanya aktif. Hal ini dapat dilakukan karena pesawat terbang telah dilengkapi dengan transponder. Pesawat-pesawat yang tidak dilengkapi transponder tidak akan dapat dilihat pada radar scope seperti identifikasi pesawat, ketinggiannya, dan lain-lain.
\end{abstract}

SSR merupakan peralatan untuk mendeteksi dan mengetahui posisi dan data target yang ada di sekelilingnya secara aktif, dimana pesawat ikut aktif jika menerima pancaran sinyal Radio Frequency (RF) radar sekunder. Pancaran radar ini berupa pulsa-pulsa mode, pesawat yang dipasangi transponder, akan menerima pulsa-pulsa tersebut dan akan menjawab berupa pulsa-pulsa code ke sistem penerima radar.

Kata Kunci - Navigasi, Pesawat Udara, Radar, Secondary Surveillance Radar.

\section{PENDAHULUAN}

Dasar untuk mempelajari navigasi adalah pemahaman istilah tertentu yang disebut dengan dimensi navigasi. Navigator menggunakan dimensi-dimensi posisi, arah, jarak, ketinggian, dan waktu sebagai acuan dasar (FAA, 2011).

Navigasi udara merupakan kegiatan untuk mengarahkan alat pesawat udara dari satu tempat ke tempat yang lain agar tidak keluar dari jalurnya. Navigasi juga diperlukan untuk mengurangi risiko kecelakaan pesawat yang diakibatkan oleh tabrakan dengan pesawat lainnya maupun benturan dengan bukit dan awan tebal khususnya ketika cuaca buruk atau jarak pandang pilot terbatas. Navigasi ini dilakukan pada pesawat udara yang dipandu dari darat melalui sinyal yang dipancarkan oleh instrumen terpasang pada menara (ground base) maupun sinyal dari satelit (satellite base).Kemudian dengan sinyalsinyal yang dipancarkan balik oleh pesawat, orang di darat dapat mengetahui koordinat titik lokasi pesawat tersebut berada yang kemudian digunakan untuk mengarahkan pesawat.

Radar SSR merupakan instrumen penting dalam pengamatan dan pengendalian lalu lintas udara, karena jangkauan radar yang cukup luas serta dapat memberikan informasi posisi pesawat secara real time.Radar digunakan di setiap bandara dengan cakupan wilayah tertentu sesuai dengan otoritas bandara tersebut.Hingga saat ini radar merupakan instrumen utama dan konvensional yang digunakan dalam penentuan posisi dan navigasi meskipun ICAO (International 
Civil Aviation Organization) membentuk kelompok kerja internasional sejak November 1983 yang bernama FANS (Future Air Navigation Systems). FANS bertujuan melakukan studi, identifikasi, dan konsolidasi dari konsep-konsep dan teknologi baru dalam bidang navigasi udara termasuk teknologi satelit serta memformulasikan rekomendasi bagi pengembangan bidang navigasi udara sipil di masa mendatang untuk periode 25 tahun (1990 - 2015). FANS telah mengembangkan konsep dari suatu sistem komunikasi, navigasi, dan pemantauan (CNS) terpadu yang berbasiskan pada teknologi satelit.Untuk komponen komunikasi dan pemantauan, FANS menggunakan GNSS (Global Navigation Satellite System) yang mencakup sistem-sistem satelit GPS. Pada saat ini organisasi-organisasi penerbangan banyak terlibat dengan pengembangan spesifikasi dan standar penerbangan untuk penggunaan GPS dan sistemsistem yang terkait (Abidin, 2007).

Analisis dalam tugas akhir ini adalah bagaimana menentukan posisi pesawat udara dengan menggunakan Secondary Surveillance Radar (SSR), informasi apa saja yang didapat dan bagaimana posisi tersebut dapat digambarkan pada peta dengan asumsi bidang datar dan bidang lengkung.

\section{OBSERVASI DATA RADAR DAN PERHITUNGAN POSISI PESAWAT}

\section{Secondary Surveillance Radar (SSR)}

SSR merupakan peralatan untuk mendeteksi dan mengetahui posisi dan data target yang ada di sekelilingnya secara aktif, dimana pesawat ikut aktif jika menerima pancaran sinyal RF radar sekunder. Pancaran radar ini berupa pulsa-pulsa mode, pesawat yang dipasangi transponder, akan menerima pulsa-pulsa tersebut dan akan menjawab berupa pulsa-pulsa code ke sistem penerima radar (DirHub, 2008).

Dalam sistem pemantauan lalu lintas udara, radar primer dirasakan kurang sempurna.Oleh karena itu, dikembangkan sistem radar yang tidak hanya memanfaatkan sinyal pantul, tetapi terjadi timbal balik antara peralatan didarat dengan peralatan radar yang ada di pesawat udara.Sistem yang dikembangkan tersebut adalah radar sekunder atau secondary surveillance radar (SSR).
Pada sistem SSR ground pemancar/penerima disebut interogator, dan pada pesawat udara penerima/pemancar disebut transponder. Interrogator transmisi dibuat pada frekuensi $1030 \mathrm{MHz}$ (sekitar $29 \mathrm{~cm}$ ) dan disebut mode.Pada interrogator menerima sinyal pada mode yang sudah diatur, transponder menanggapi dengan transmisi pada frekuensi $1090 \mathrm{MHz}$. Tanggapan ini adalah dalam bentuk kode. Semua sistem SSR sipil saat ini menggunakan frekuensi yang sama yaitu 1030MHz untuk ground untuk transmisi ke udara, dan $1090 \mathrm{MHz}$ untuk udara untuk transmisi ke ground.

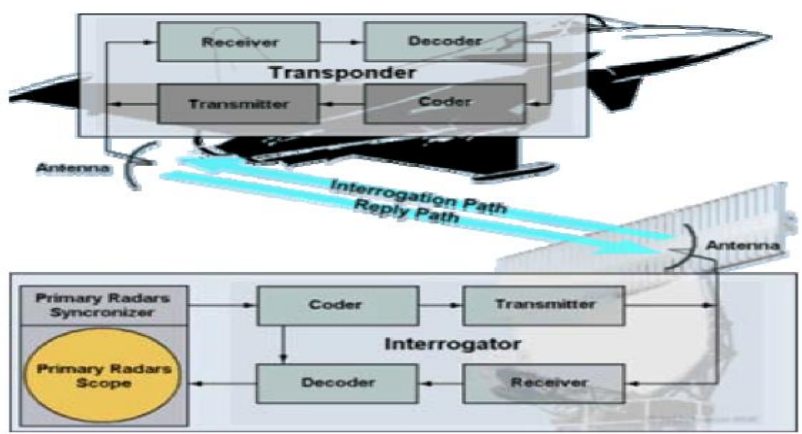

Gambar 1. Diagram Kinerja Radar SSR (Jacob, 1993)

Informasi yang didapat dari radar SSR adalah jarak pesawat, posisi pesawat, kode pesawat, ketinggian pesawat dan kecepatan pesawat.

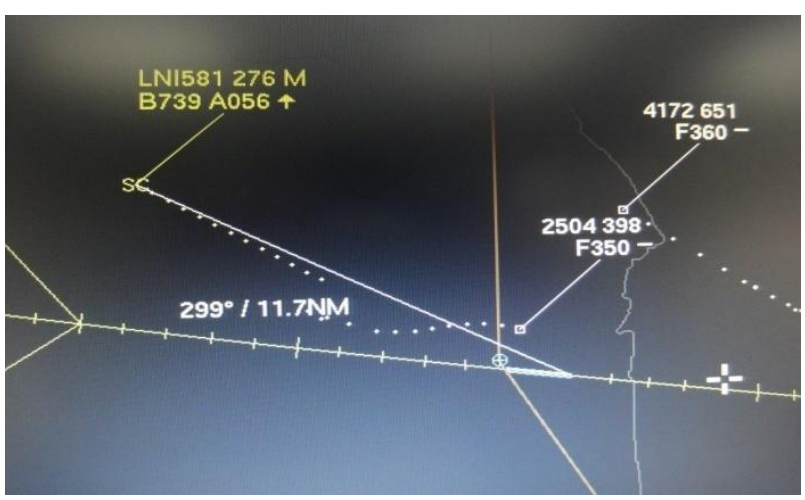

Gambar 2. Display Monitor Radar SSR

\section{Perhitungan Jelajah Ketinggian Terbang}

Dalam penerbangan ketinggian diukur dengan menggunakan tekanan altimeter yang beracuan pada barometer. Altimeter mengukur tekanan udara yang menurun dengan meningkatnya ketinggian mengikuti rumus barometer dan dari tekanan sekitarnya dapat dihitung ketinggian yang sesuai. 
Flight Level (FL) adalah tekanan udara tertentu yang dinyatakan sebagai nominal ketinggian ratusan meter.Tekanan dihitung dengan asumsi standar internasional tekanan permukaan laut $1.013,25 \mathrm{hPa}(29,92 \mathrm{inHg})$. Karena tekanan dihitung berdasarkan tekanan udara maka ketinggian yang didapat belum tentu sama dengan ketinggian sejati pesawat baik di atas berarti permukaan laut atau di atas permukaan tanah (Farrel, 1976).

$$
\begin{aligned}
& 1 \mathrm{FL} \quad=100 \mathrm{ft} \\
& 1 \mathrm{ft} \quad=0.3048 \mathrm{~m}
\end{aligned}
$$

\section{Perhitungan Kecepatan Pesawat}

Airspeed Indicator (ASI), diukur dari pitot tube dan barometric static port, dari alat tersebut didapat indicated airspeed (IAS). Dengan static port IAS dikoreksi untuk tekanan udara di sekitarnya, tetapi tidak untuk kerapatan udara.Rasio antara tekanan dan kepadatan bergantung pada temperatur udara - sesuai hukum ideal gas (FAA, 2010).

Pada permukaan laut dalam International Standart Atmosphere (ISA) dan pada kecepatan rendah di mana kompresibilitas udara diabaikan, IAS sesuai dengan TAS. Ketika kepadatan udara atau suhu di sekitar pesawat berbeda dari kondisi permukaan laut standar, IAS tidak akan lagi sesuai dengan TAS, sehingga tidak lagi menyatakan pergerakan pesawat secara akurat. ASI akan menunjukkan kurang dari TAS ketika kepadatan udara menurun karena peningkatan ketinggian

\begin{tabular}{|c|c|c|c|c|c|}
\hline & $\mathrm{m} / \mathrm{s}$ & $\mathrm{km} / \mathrm{h}$ & $\mathrm{mph}$ & knot & $\mathrm{ft} / \mathrm{s}$ \\
\hline $1 \mathrm{~m} / \mathrm{s}=$ & 1 & 3.6 & 2.236 936 & 1.943844 & 3.280840 \\
\hline $1 \mathrm{~km} / \mathrm{h}=$ & 0.2 & 1 & 0.621371 & 0.5 & 0.9 \\
\hline $1 \mathrm{mph}=$ & 0.44704 & 1.6 & 1 & 0.868976 & 1.466667 \\
\hline $1 \mathrm{knot}=$ & 0.514444 & 1.852 & 1.150779 & 1 & 1.687810 \\
\hline $1 \mathrm{ft} / \mathrm{s}=$ & 0.3048 & 1.09728 & 0.681818 & 0.592484 & 1 \\
\hline
\end{tabular}
atau temperatur.

Gambar 3. Konversi Satuan Kecepatan

\section{Perhitungan Posisi Pesawat}

Untuk mencari posisi pesawat digunakan rumus sebagai berikut, posisi ini diasumsikan sebagai planimetris atau bidang datar yaitu (Wolf, 2002) :

$$
\begin{aligned}
& \text { Mencari } X \\
& \Delta x=d \sin \alpha \\
& x=x_{0}+\Delta x
\end{aligned}
$$

Mencari $Y$

$\Delta y=d \cos a$

$y=y_{0}+\Delta y$

Dimana:

$\Delta x=$ Selisih antara titik yang diketahui dengan

$\overline{\Delta y} \quad$ titik yang dicari

d = Jarak antara titik yang diketahui dengan titik yang dicari

a = sudut azimuth

$\frac{x_{0}}{y_{0}}=$ titik yang diketahui

Semua posisi pesawat yang dicari dihitung dari titik yang diketahui yaitu titik Runway 28 Bandara Juanda Surabaya. Sistem koordinat yang digunakan adalah Universal Transverse Mercator (UTM).

\section{Segitiga Bola}

Segitiga bola adalah suatu bidang lengkung pada permukaan bola yang dibatasi oleh perpotongan tiga lingkaran konsentris yang pusatnya berimpit pada pusat bola. Segitiga bola memiliki 3 sudut dan 3 sisi, di mana semuanya dinyatakan dalam satuan sudut. Sisi segitiga bola merupakan bagian dari busur lingkaran terbesar yang dapat dibuat pada bidang bola:

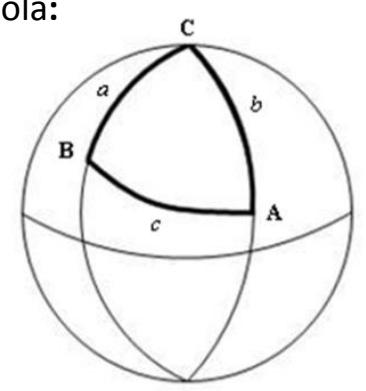

\section{Gambar 4. Segitiga Bola}

Pada gambar 5 huruf besar menyatakan titik-titik sudut segitiga bola, sedangkan huruf kecil menyatakan sisi segitiga bola. Pada segitiga bola berlaku beberapa aturan yang menjelaskan 
hubungan matematis antara sisi-sisi dan sudutsudut segitiga bola. Dari sekian banyak aturan tersebut, ada 2 aturan yang paling mendasar yaitu:

\section{Aturan Cosinus}

$\cos \alpha=\cos b \cos c+\sin b \sin c \cos \mathrm{A}$

$\cos b=\cos \alpha \cos c+\sin \alpha \sin c \cos \mathrm{B}$

$\cos c=\cos \alpha \cos b+\sin \alpha \operatorname{sib} b \cos$

Aturan Sinus

$$
\frac{\sin a}{\sin A}=\frac{\sin b}{\sin B}=\frac{\sin C}{\sin C}
$$

Menentukan posisi dengan menggunakan rumus segitiga bola:

$$
\alpha=\frac{d 360^{\circ}}{2 \pi r}
$$

Dimana:

$$
\begin{aligned}
\alpha & =\text { Posisi } \\
\mathrm{d} & =\text { Jarak }(\mathrm{m}) \\
\tau & =\text { Sumbu panjang bumi }(6378137 \mathrm{~m})
\end{aligned}
$$

\section{Datum Global ( World Geodetic System 1984)}

WGS 1984 merupakan realisasi dari sistem koordinat CTS yang pertaman kali direalisasikan dengan memodifikasi kerangka referensi yang digunakan oleh satelit doppler (NSWC 9Z-2). WGS 84 didefinisikan dan dijaga oleh Defence Mapping Agency ( DMA ) amerika serikat sebagai datum global geodetik. Ellipsoid yang digunakan dalam WGS 84 memiliki parameter sebagai berikut (Abidin, 2005) :

$\begin{array}{ll}\text { Sumbu panjang }(\mathrm{a}) & =6378137.0 \mathrm{~m} \\ \text { Penggepengan }(\mathrm{i} / \mathrm{f}) & =298.257228563 \\ \text { Kecepatan sudut bumi }(\omega & =7292115 \times 10^{11} \mathrm{rad} \mathrm{s}^{-1} \\ \text { Konstanta gravitasi bumi }(\mathrm{GM})=8986004.418 \times 10^{8} \mathrm{~m}^{3} \mathrm{~s}^{2}\end{array}$

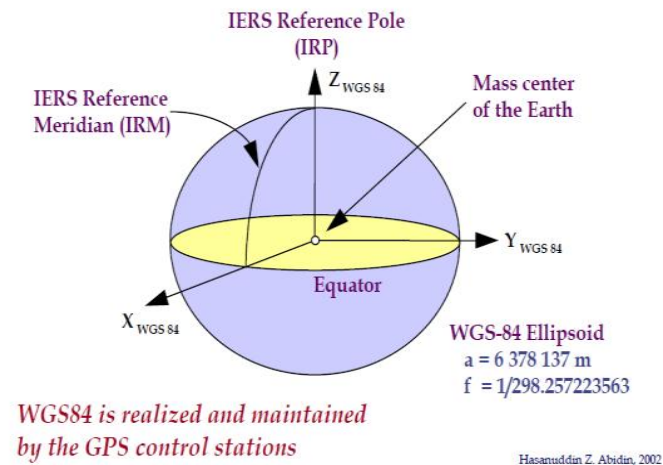

Gambar 5. Datum Global WGS 84

\section{Perhitungan Root Mean Square Error (RMSE)}

Root Mean Square Error (RMSE) adalah ukuran perbedaan antara nilai besaran yang diprediksi dengan nilai yang diamati sebenarnya. RMSE adalah ukuran akurasi dari suatu prediksi besaran dan didefinisikan dengan persamaan:

RMSE $=\sqrt{\frac{\sum_{i=1}^{n}\left(x_{1, i}-x_{2, i}\right)^{2}}{n}}$

Dimana:

$\mathrm{x}_{1, \mathrm{i}} \quad=$ nilai prediksi ke $\mathrm{i}$,

$\mathrm{x}_{2, \mathrm{i}} \quad=$ adalah nilai pengamatan ke i dan

$\mathrm{n} \quad=$ adalah jumlah pengamatan.

\section{METODOLOGI PENELITIAN}

Lokasi penelitian adalah PT. Angkasa Pura I (Persero) Bandara Juanda Surabaya yang berlokasi pada koordinat $07^{\circ} 22^{\prime} 28.92^{\prime \prime}$ LS dan $112^{\circ} 47^{\prime} 41.39^{\prime \prime}$ BT dengan Elevasi $2.74 \mathrm{~m} / 9.00 \mathrm{ft}$ (MSL).Wilayah jangkauan radar Bandara Juanda sejauh 200 Nautical Miles atau 370 km dari titik pusat radar. Observasi dan akuisisi data radar dilakukan pada tanggal 7 April 2013 di Radar Center PT. Angkasa Puta I Bandara Juanda Surabaya.

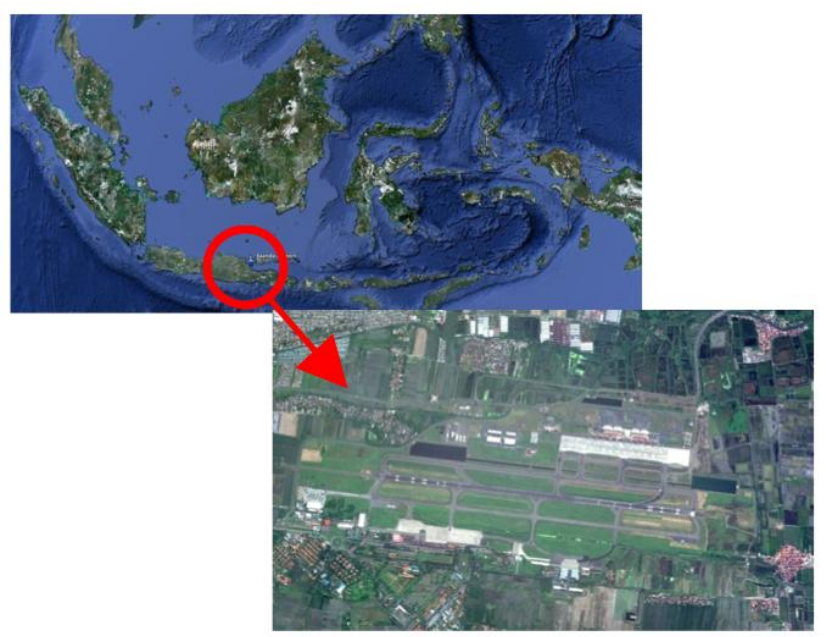

Gambar 6. Lokasi penelitian: PT. Angkasa Pura I (Persero) Bandara Juanda Surabaya 
Diagram alir tahap pengolahan data:

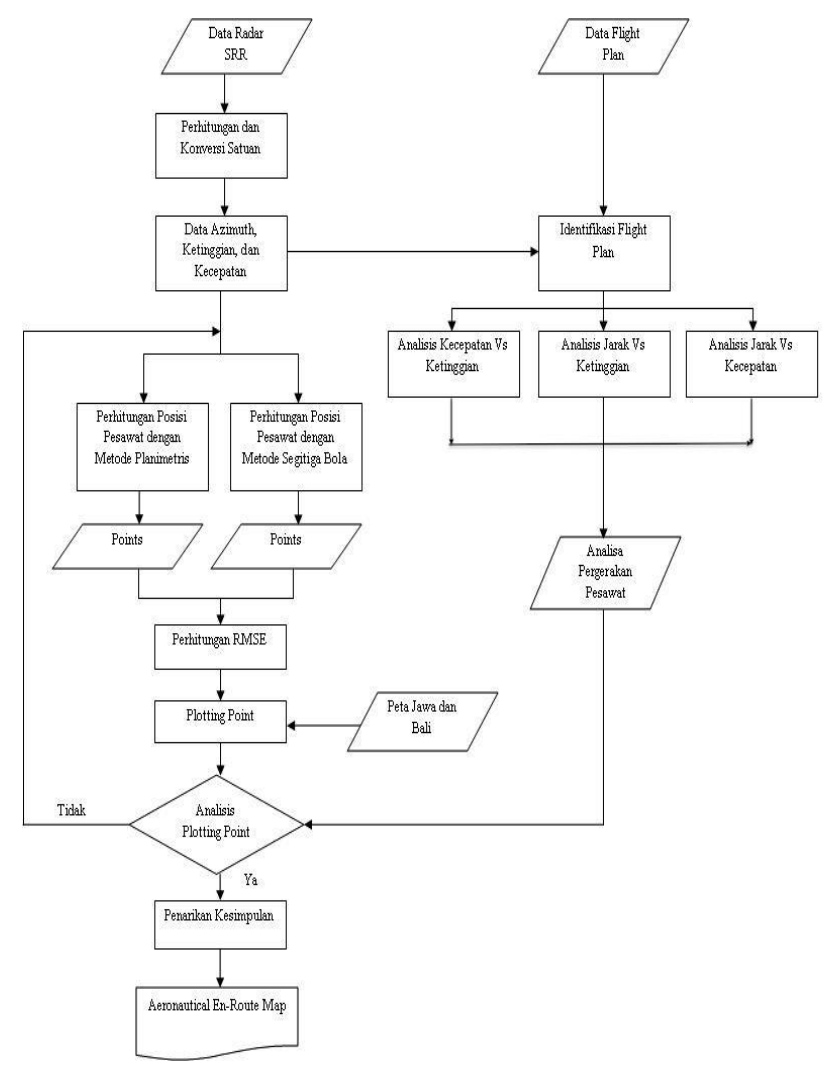

Gambar 7. Diagram tahap pengolahan data

\section{HASIL DAN ANALISA}

Dari data flight plan diperoleh informasi penerbangan pesawat. Dalam penelitian ini terdapat tujuh objek pesawat yang diobservasi. Semua penerbangan adalah penerbangan komersial dan berjadwal yang terdiri dari arrival flight, departure flight dan over flight, yaitu:

$\begin{array}{ll}\text { GIA713 } & \text { : Garuda Indonesia (Over Flight) } \\ \text { WON1846 } & \text { : Wings Air (Arrival Flight) } \\ \text { LN1581 } & \text { : Lion Air (Departure Flight) } \\ \text { SJY567 } & \text { : Sriwijaya Air (Arrival Flight) } \\ \text { WON1818 } & \text { : Wings Air (Departure Flight) } \\ \text { KLM835 } & \text { : Royal Dutch Airlines } \\ & \text { KLM(Arrival Flight) } \\ \text { AWQ8294 } & \text { : Air Asia (Arrival Flight) }\end{array}$

\section{Analisis Jarak dan Ketinggian Pesawat}
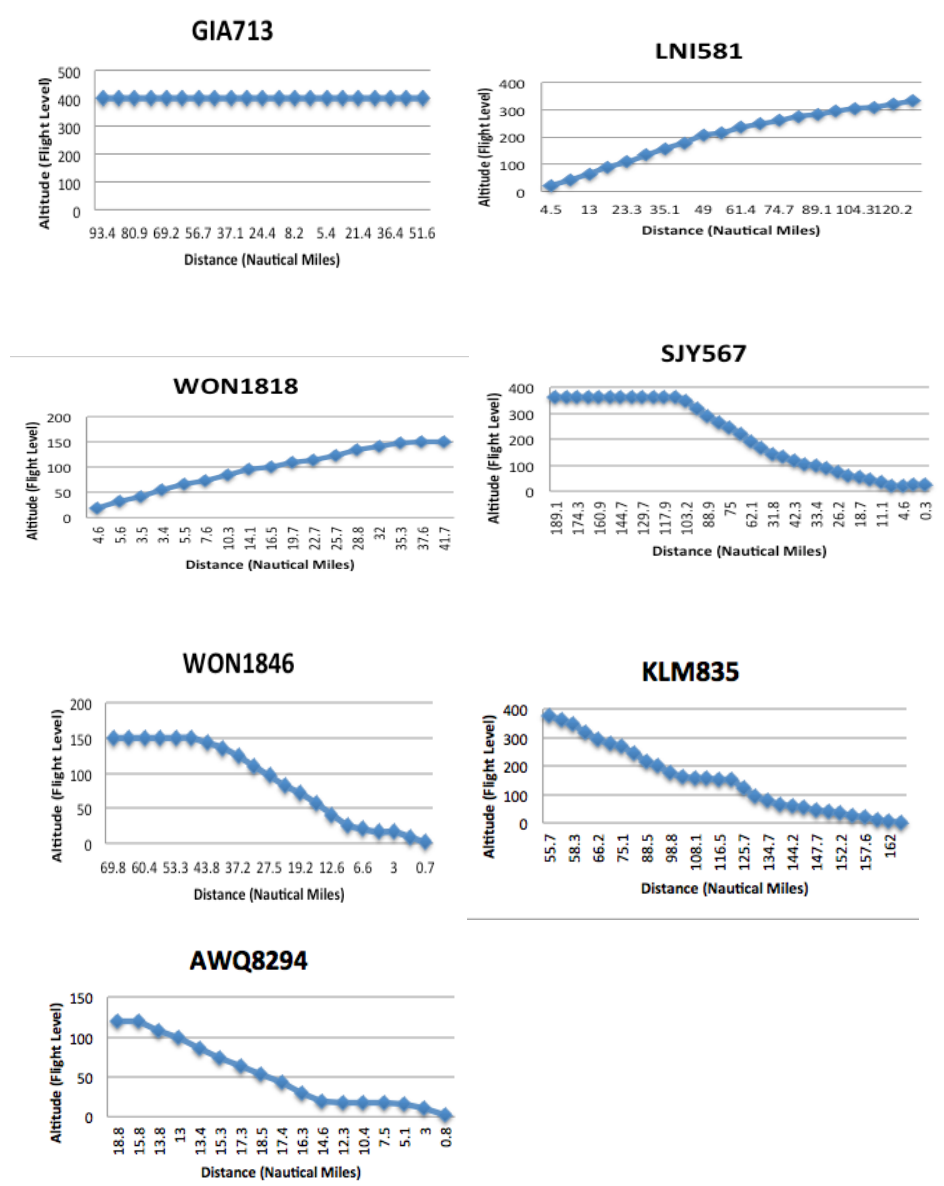

Gambar 8. Grafik Jarak VS Ketinggian

Dari fungsi grafik diatas menunjukkan bahwa pada penerbangan departure flight semakin jauh jarak pesawat maka ketinggian terbang pesawat akan semakin meningkat hingga pada ketinggian tertentu. Pada penerbangan arrival flight semakin dekat jarak pesawat dengan bandara Juanda maka ketinggian pesawat juga semakin menurun. Hal ini dikarenakan pesawat sedang dalam proses landing approach. Dalam tahap ini secara berturut-turut pesawat menurunkan ketinggiannya hingga menyentuh landasan pacu.

Pada grafik penerbangan over flight pesawat GIA713 menunjukkan bahwa jarak tidak mempengaruhi ketinggian terbang. Pesawat ini tetap terbang pada ketinggian yang stabil 400FL. Pada Pesawat KLM835 menunjukkan bahwa semakin jauh jarak pesawat maka ketinggian akan semakin menurun, hal ini dikarenakan pesawat tersebut mendarat di bandara Ngurah Rai Denpasar. 


\section{Analisis Jarak dan Kecepatan Pesawat}
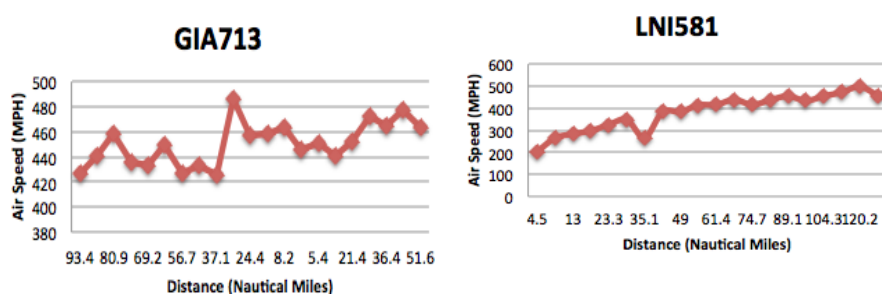

WON1818

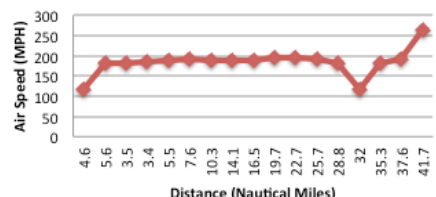

WON1846

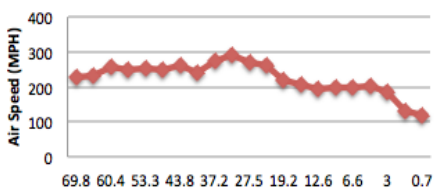

Distance (Nautical Miles)

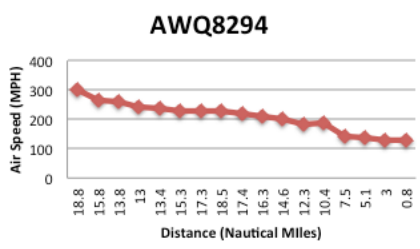

Gambar 9. Grafik Jarak VS Kecepatan

Grafik diatas menunjukkan bahwa pada penerbangan departure flight semakin jauh jarak pesawat maka kecepatan pesawat akan meningkat. Pada penerbangan arrival flight semakin dekat jarak pesawat dengan bandara maka kecepatan pesawat akan menurun hingga pada kecepatan tertentu untuk landing. Pada penerbangan overflight pesawat GA713 terbang pada kecepatan tinggi antara $427-463 \mathrm{Mph}$, hal ini menunjukkan bahwa jarak tidak berhubungan dengan kecepatan. Pada pesawat KLM835 menunjukkan bahwa semakin jauh jarak pesawat maka kecepatan akan semakin menurun, hal ini dikarenakan pesawat tersebut menjauhi bandara Juanda dan mendarat di bandara Ngurah Rai Denpasar.

\section{Analisis Kecepatan dan Ketinggian Pesawat}

Fungsi grafik kecepatan dan ketinggian mirip dengan grafik jarak dan ketinggian. Pada penerbangan departure flight grafik menunjukkan bahwa semakin tinggi kecepatan pesawat maka ketinggian jelajah terbang akan semakin meningkat hingga pada ketinggian tertentu. Pada penerbangan arrival flight semakin turun kecepatan pesawat maka ketinggian jelajah terbang juga semakin menurun.

Grafik penerbangan over flight pesawat GIA713 menunjukkan bahwa kecepatan tidak mempengaruhi ketinggian jelajah terbang.
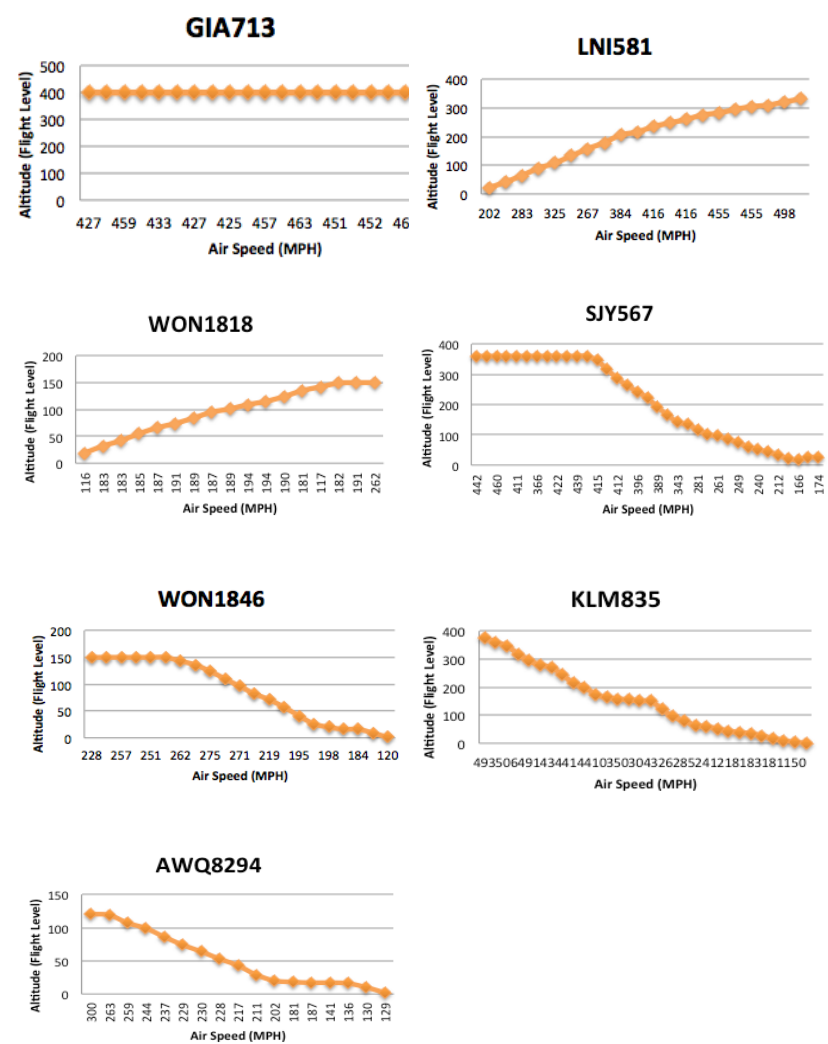

Gambar 10. Grafik Kecepatan VS Ketinggian

\section{Perhitungan Root Mean Square Error}

Nilai dari RMSE didapat dari perbaandingan hasil perhitungan posisi pesawat dengan metode planimetris dan metode segitiga bola. Hasil tersebut menunjukkan selisih perhitungan posisi pesawat yang diasumsikan terbang pada garis lurus dengan garis lengkung. Perhitungan RMSE dilakukan pada tiap pesawat. Kemudian dihitung RMSE dari semua pesawat. 


\begin{tabular}{|c|c|c|}
\hline No & Pesawat & RMSE $(m)$ \\
\hline 1 & GIA713 & 9380.94 \\
\hline 2 & WON1846 & 1700.55 \\
\hline 3 & LNI581 & 18162.5 \\
\hline 4 & SJY567 & 15596.25 \\
\hline 5 & WON1818 & 5564.96 \\
\hline 6 & KLM835 & 35837.49 \\
\hline 7 & AWQ8294 & 27204.65 \\
\hline & RMSE Total $=$ & 16206.76 \\
\hline
\end{tabular}

Gambar 11. Hasil Perhitungan RMSE

Pola nilai RMSE adalah acak. Pesawat dengan ketinggian terbang diatas $350 \mathrm{FL}$ memiliki nilai RMSE yang sangat besar seperti KLM835 dan SJY567. GIA713 terbang stabil pada ketinggian jelajah \$400FL memiliki nilai RMSE yang tidak terlalu besar jika dibanding dengan KLM835 dan SJY567.

Pesawat jenis turbo propiler atau jenis pesawat menggunakan turbin gas untuk menggerakkan baling-baling seperti Wings Air WON1846 dan WON1818 yang menggunakan pesawat type ATR72 memiliki RMSE yang relatif kecil yaitu masing-masing $1700.55 \mathrm{~m}$ dan $5564.96 \mathrm{~m}$ karena pesawat ini terbang tidak terlalu tinggi yaitu pada ketinggian jelajah 150FL.

Secara umum tidak ada korelasi antara besar kecilnya nilai RMSE dengan pola pergerakan pesawat karena persebaran nilai RMSE adalah acak.

\section{Aeronautical en-route map}

Setelah dilakukan analisa grafik pergerakan pesawat dan verifikasi posisi pesawat yang diplot pada peta dengan posisi pesawat pada radar maka didapat kesimpulan bahwa posisi yang dihitung secara planimetris sangat presisi dengan posisi pesawat pada radar, sedangkan posisi pesawat yang dihitung dengan menggunakan metode segiiga bola mengalami pergeseran dari posisi pesawat yang di radar.

Berikut adalah pengambaran posisi pesawat pada peta jalur terbang atau aeronautical en-route maps:

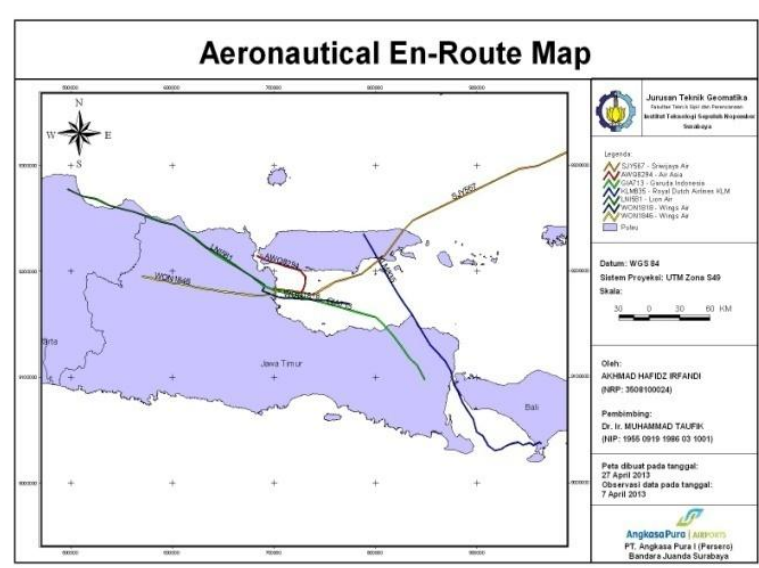

Gambar 6. Aeronautical En-Route Map

\section{KESIMPULAN DAN SARAN}

Radar SSR menghitung jarak secara mendatar bukan secara lengkung. Sudut azimuth beracuan pada true north atau utara kutub hal ini dikarenakan navigasi penerbangan berrefrensi secara global.Ketinggian pesawat bukanlah absolute altitude (ketinggian sejati) ketinggian diperoleh dengan menggunakan tekanan altimeter yang beracuan pada barometer dan dinyatakan dalam FL (flight level). Kecepatan pesawat diukur dengan alat yang bernama pitot tube yang kemudian ditampilkan pada Air Speed Indicator (AIS), informasi ini juga dipancarkan oleh pesawat ke ground base dan ditangkap melalui antena Radar.

Dari hasil perhitungan pesawat dengan menggunakan metode planimetris dan metode segitiga bola maka didapat angka RMSE sebesar 16206.76. RMSE terbesar terbesar adalah pesawat Royal Dutch Airlines KLM KLM835 dengan nilai $35837.49 \mathrm{~m}$ dan RMSE terkecil adalah pesawat Wings Air WON1846 dengan nilai $1700.55 \mathrm{~m}$. Tidak ada korelasi nilai RMSE dengan pola pergerakan pesawat, jarak tempuh, kecepatan dan ketinggian jelajah terbang karena persebaran nilai RMSE adalah acak.

Perhitungan posisi pesawat dengan metode planimetris lebih presisi dibandingkan dengan perhitungan metode segitiga bola. Hasil ploting points metode planimetris sesuai dengan posisi pesawat pada radar, sedangkan hasil perhitungan dengan metode segitiga bola tidak sesuai dengan posisi pesawat pada radar. 
Dalam proses observasi dan akuisisi data hendaknya data diambil dalam interval waktu yang lebih teratur, rute terbang yang lebih bervariasi, jarak yang lebih panjang dan variasi penerbangan yang lebih banyak. Untuk penelitian selanjutnya dapat diteliti kemungkinan penggunaan jenis radar lain dengan spesifikasi yang lebih tinggi.

Penelitian berikutnya dapat membandingkan metode penentuan posisi pesawat udara dengan menggunakan GPS dan Radar. Apa saja yang menjadi kekurangan dan keunggulan masingmasing

\section{DAFTAR PUSTAKA}

Abidin, H.Z. 2007. GPS dan Perhubungan Udara. Bandung

Abidin, H.Z., Sutisna, S., Padmasari, T., Kahar. J., Villanueva. K.j., 2005. Geodetic Datum Of Indonesia Maritime Boundaries : Status And Problems. Cairo, Egypt, April 16-21.

Arfianda, N. 2011. Basic Pilot Training. Jakarta. IVAO Indonesia Division Document

Aviation Theory Centre. 2005. Navigation for The CASA PPL/CPL Day VFR Syllabus. Melbourne. Aviation Theory Centre Press

Directorate General of Air Communications. 1995. Secondary Surveillance Radar Basic Theory. Medan. PT. Angkasa Pura II (Persero) Medan

Direktorat Jenderal Perhubungan Udara. 2009. Aeronautical Information Publication (AIP). Jakarta

Direktorat Jenderal Perhubungan Udara. 2008. Secondary Surveillance Radar (SSR). Jakarta. Direktorat Fasilitas Elektronika dan Listrik Penerbangan. Jakarta

Farrell, J.L. 1976. Integrated Aircraft Navigation. Academic Press.

Federal Aviation Administration. Flight Navigation Handbook. US Department of Transportation, 2011

Jacob, dkk. 1993. Air Navigation for Civil Aviation. Global Science Press

Mawaddah. 2010. Studi Tentang Secondary Surveillance Radar (SSR) Untuk Menentukan Berbagai Informasi Pesawat Terbang Di PT. Angkasa Pura II Polonia Medan. Medan

Nurdjati, C. 1999. Buku Ajar Ilmu Ukur Tanah. Surabaya. ITS Press.
Wolf, P.R., dan Ghilani, C.G. 2002. Elementary Surveying : Tenth Edition. New Jersey, USA. Pearson Education International.

Yusuf, E.S. 2008. Teknik Radar. Medan. Akademi Teknik dan Keselamatan Penerbangan (ATKP) 